\title{
Tingkat Partisipasi Anggota Kelompok Tani di Kampung Sayur Bausasran Kecamatan Danurejan Kota Yogyakarta
}

\section{Participation Rate of Farmer Group Members in Kampung Sayur Bausasran, Danurejan District, Yogyakarta City}

\author{
Sita Diani Putri \\ Program Studi Magister Agribisnis Fakultas Pertanian \\ Universitas Pembangunan Nasional (Veteran) Yogyakarta
}

\section{ARTICLE INFO}

Article history:

DOI:

$\underline{10.30595 / p s p f s . v 2 i .198}$

Submitted:

July 29, 2021

Accepted:

Sept 10, 2021

Published:

Nov 10, 2021

Keywords:

Participation Rate, Participation Factor, Kampung Sayur

Bausasran

\begin{abstract}
This research aimed to (1) analyze participation rate of farmer group members in Kampung Sayur Bausasran, and (2) analyze the influence of factors such as education level, main ocupation, vegetable farming experience, extension officer performance and Government facilitation towards the participation of farmers group members in Kampung Sayur Bausasran. Research implementation method used was quantitative method with descriptive approach. Method of determining the research location used was purposive method namely in Kampung Sayur Bausasran, Danurejan, Yogyakarta. Sample taking method used was proportional cluster random sampling method. Data type used in this research are primary and secondary data. Data collecting method were by taking interview, documentation and observation. To analyze the influence of factors such as education level, main livelihood, vegetable farming experience, extension officer performance and Government facilitation towards farmers group member, multiple linear regression analysis was used. This research result showed that (1) participation rate of famer group member in Kampung Sayur Bausasran was high, and (2) factors such as education level, main ocupation, vegetable farming experience, extension officer performance, and Government facilitation significantly affected the participation rate of famer group members in Kampung Sayur Bausasran.
\end{abstract}

This work is licensed under a Creative Commons Attribution 4.0 International License.

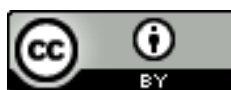

Corresponding Author:

Sita Diani Putri

Program Studi Magister Agribisnis Fakultas Pertanian

Universitas Pembangunan Nasional (Veteran) Yogyakarta

Email: sitadianiputri@gmail.com

\section{PENDAHULUAN}

Undang-undang No. 18 Tahun 2012 Tentang Pangan mengartikan Ketahanan Pangan sebagai kondisi terpenuhinya pangan bagi rumah tangga yang tercermin dari tersedianya pangan yang cukup baik jumlah maupun mutunya, aman, merata dan terjangkau. Apabila keadaan tersebut tidak terpenuhi maka kemungkinan terjadi kerawanan pangan. Kerawanan pangan terjadi apabila penduduk mengalami kekurangan gizi yang disebabkan oleh tidak tersedianya pangan secara sementara atau terus-menerus, kurangnya akses sosial atau ekonomi terhadap pangan yang cukup, dan atau konsumsi serta penyerapan bahan pangan yang tidak memadai. 
Kerawanan pangan dapat berupa fenomena jangka pendek (sementara) yang timbul karena terjadinya bencana, atau merupakan masalah jangka panjang (kronis) yang disebabkan oleh keterbelakangan kondisi sosial ekonomi yang tidak menguntungkan (Badan Ketahanan Pangan dan Penyuluhan DIY, 2018).

Rencana Pembangunan Jangka Menengah Daerah (RPJMD) Kota Yogyakarta Periode 2017 - 2022 mengamanatkan ketahanan pangan sebagai salah satu Sasaran Daerah dengan Skor Pola Pangan Harapan (PPH) sebagai indikator kinerjanya. PPH adalah indikator kualitas konsumsi pangan yang dipengaruhi oleh keragaman dan keseimbangan konsumsi antar-kelompok pangan. Skor PPH Kota Yogyakarta Tahun 2018 dan 2019 menunjukkan bahwa pola konsumsi pangan di Kota Yogyakarta belum ideal secara merata pada berbagai kelompok pangan, dalam hal ini adalah kelompok pangan buah dan sayur. Salah satu upaya untuk meningkatkan konsumsi sayur dan buah adalah dengan mendekatkan masyarakat sedekat mungkin dengan sumber pangan sayur dan buah melalui pemanfaatan pekarangan. Dinas Pertanian dan Pangan Kota Yogyakarta telah melaksanakan berbagai program dan kegiatan dalam upaya pemanfaatan pekarangan dalam rangka peningkatan ketahanan pangan, salah satunya melalui Program Kampung Sayur di seluruh wilayah Kota Yogyakarta.

Salah satu kampung yang berhasil dalam pengelolaan kampung sayur berada di wilayah Kelurahan Bausasran, Kecamatan Danurejan, Kota Yogyakarta. Suksesnya pelaksanaan kebijakan dan program yang telah dirumuskan oleh pemerintah sangat tergantung pada partisipasi dan dukungan masyarakat yang menjadi pemeran dan pelaksana utama di lapangan. Menurut penelitian terdahulu yang dilakukan oleh Andry (2020), tingkat partisipasi petani dipengaruhi oleh umur. Sedangkan menurut penelitian yang dilakukan oleh Wahyuni (2021), tingkat partisipasi petani dipengaruhi oleh pengetahuan petani, sarana dan prasarana serta pihak yang mendukung. Berbeda dengan penelitian-penelitian tersebut, penelitian ini menggunakan dimensi, indikator dan variabel yang berbeda. Penelitian ini menganalisis partisipasi anggota kelompok tani pada dimensi pengetahuan, dimensi kemauan dan dimensi tindakan. Variabel bebas dalam penelitian ini adalah tingkat pendidikan, mata pencaharian utama, pengalaman berusahatani sayuran, kinerja Penyuluh dan fasilitasi pemerintah dengan uji analisis deskriptif dan Regresi Linear Berganda. Dari variabel bebas tersebut diduga bahwa variabel tingkat pendidikan, mata pencaharian utama, pengalaman berusahatani sayuran, kinerja penyuluh dan fasilitasi pemerintah berpengaruh signifikan terhadap partisipasi anggota kelompok tani di Kampung Sayur Bausasran. Variabel kinerja Penyuluh dan fasilitasi pemerintah adalah variabel baru yang belum digunakan pada penelitian sebelumnya.

Tujuan penelitian ini yaitu (1) menganalisis tingkat partisipasi anggota kelompok tani di Kampung Sayur Bausasran, dan (2) menganalisis pengaruh faktor tingkat pendidikan, mata pencaharian utama, pengalaman berusahatani sayuran, kinerja penyuluh dan fasilitasi pemerintah terhadap partisipasi anggota kelompok tani di Kampung Sayur Bausasran.

\section{METODE PENELITIAN}

\section{Metode Pelaksanaan Penelitian} deskriptif.

Jenis penelitian yang digunakan dalam penelitian ini adalah penelitian kuantitatif dengan metode

\section{Metode Penentuan Lokasi}

Penelitian dilakukan di Kampung Bausasran, Kelurahan Bausasran, Kecamatan Danurejan, Kota Yogyakarta. Waktu penelitian dilakukan dari bulan Desember Tahun 2020 sampai bulan Maret tahun 2021.Kampung Bausasran dipilih menjadi daerah penelitian secara sengaja (purposive) dengan pertimbangan bahwa Kampung Bausasran adalah Juara I Lomba Kampung Sayur Kota Yogyakarta Tahun 2019.

\section{Metode Penentuan Sampel}

Populasi dalam penelitian ini adalah seluruh anggota kelompok tani di wilayah Kampung Bausasran, Kelurahan Bausasran, Kecamatan Danurejan, Kota Yogyakarta yaitu sebanyak 5 kelompok tani dengan jumlah populasi sebanyak 106 orang. Data kelompok tani yang berada di wilayah Kampung Bausasran disajikan dalam tabel berikut:

Tabel 1. Kelompok Tani di Kampung Bausasran

\begin{tabular}{|c|c|c|c|c|c|}
\hline No & Nama Kelompok & Alamat & $\begin{array}{l}\text { Tahun } \\
\text { Berdiri }\end{array}$ & Nama Ketua & $\begin{array}{c}\text { Jml } \\
\text { Anggota }\end{array}$ \\
\hline 1 & KTD Gemah Ripah & $\begin{array}{l}\text { Bausasran DN } 3 \text { / } 619 \text { Rw } 09 \\
\text { Danurejan }\end{array}$ & 2009 & Winaryati & 25 orang \\
\hline 2 & KWT Amanah & $\begin{array}{l}\text { Jln.Danurejan No.819 Rw } 10 \\
\text { Danurejan }\end{array}$ & 2012 & Ratna Meiliana S.Ag & 19 orang \\
\hline 3 & $\begin{array}{l}\text { KTD Bonjowi } 4 \\
\text { Dasa }\end{array}$ & Bausasran DN 3 / 679 RT40/RW10 & 2015 & Endang Wahyu W & 22 orang \\
\hline 4 & KTD Bustan Adi & Bausasran DN 3 / 5783 Rw 11 & 2019 & Sumartinah & 20 orang \\
\hline
\end{tabular}

Proceedings homepage: https://conferenceproceedings.ump.ac.id/index.php/pspfs/issue/view/9 


\begin{tabular}{ccccc}
5 & $\begin{array}{l}\text { Danurejan } \\
\text { KTD Sumur Bening } \\
\text { Bausasran DN 3 / 995 RT. } \\
\text { RW 10 }\end{array}$ & 2019 & Wanurti Indri Utami & 20 orang \\
\hline & Jumlah & 106 orang \\
\hline
\end{tabular}

Sumber : Database Kelompok Tani Tahun 2019.

Dari 106 orang populasi tersebut selanjutnya ditentukan sampel dengan metode Proportional Cluster Random Sampling yaitu teknik pengambilan sampel pada populasi yang terdiri atas beberapa sub populasi atau kelompok dengan mengambil sampel dari tiap - tiap sub populasi yang jumlahnya disesuaikan dengan jumlah anggota dari masing-masing sub populasi secara acak.

Ukuran sampel menggunakan rumus dari Taro Yamane atau Slovin (Riduwan, 2013) yaitu:

$$
\begin{aligned}
n & =\frac{N}{N d^{2}+1} \\
& =\frac{106}{\left(106 \times 0.1^{2}\right)+1} \\
& =\frac{106}{\left(106 \times 0.1^{2}\right)+1}
\end{aligned}
$$

$=51,45$ dibulatkan menjadi 52 sampel

Seluruh sampel tersebar dalam 5 klaster atau kelompok tani. Agar semua kelompok dapat diambil sampelnya, maka peneliti menghitung jumlah sampel pada masing - masing kelompok dengan rumus sebagai berikut:

Jumlah Sampel Setiap Kelompok $=\frac{\text { Jumlah Anggota Kelompok }}{106} \times 52$

Sehingga jumlah sampel pada masing-masing kelompok yaitu:

Tabel 2. Jumlah Sampel Pada Setiap Kelompok Tani

\begin{tabular}{lll}
\hline No & \multicolumn{1}{c}{ Nama Kelompok } & Jumlah Sampel \\
\hline 1. & KTD Gemah Ripah & $\frac{25}{106} \times 52=12,2=12$ \\
2. & KWT Amanah & $=\frac{19}{106} \times 52=9,32=9$ \\
3. & KTD Bonjowi 4 Dasa & $=\frac{22}{106} \times 52=10,79=11$ \\
4. & KTD Bustan Adi & $=\frac{20}{106} \times 52=9,81=10$ \\
5. & KTD Sumur Bening & $=\frac{20}{106} \times 52=9,81=10$ \\
\hline & Jumlah & 52 \\
\hline
\end{tabular}

Sumber : Data diolah

\section{Jenis dan Sumber Data}

Jenis data yang sering digunakan dalam penelitian adalah data kualitatif dan data kuantitatif. Dalam penelitian ini penulis menggunakan dua sumber data yaitu data primer dan data sekunder.

\section{Metode Pengambilan Data}

Metode pengumpulan data yang digunakan dalam penelitian ini adalah observasi, wawancara dan dokumentasi.

\section{Uji Coba Instrumen} reabilitas.

Sebelum kuesioner disebarkan kepada responden, terlebih dahulu dianalisis dengan uji validitas dan uji

\section{Teknik Analisis Data}

\section{Uji Asumsi Klasik}

Untuk memberikan kepastian bahwa persamaan regresi yang didapatkan memiliki ketepatan dalam estimasi, menunjukkan hubungan signifikan dan representative, maka model tersebut harus memenuhi asumsi 
klasik regresi. Uji asumsi klasik yang dilakukan yaitu uji normalitas, uji hetereskedatisitas dan uji multikolinearitas.

\section{Tingkat partisipasi anggota kelompok tani}

Tingkat partisipasi anggota kelompok tani diukur dengan cara memberikan kuesioner kepada responden. Jawaban - jawaban yang tercantum dalam kuesioner mengacu pada Skala Likert dengan menggunakan skor 1 3. Skala Likert dengan kriteria sebagai berikut :

Tabel 3. Alternatif Jawaban Responden dan Skor Penilaian

\begin{tabular}{lcc}
\hline \multicolumn{1}{c}{ Pilihan jawaban } & Skor pernyataan positif & Skor pernyataan negatif \\
\hline Tidak Setuju & 1 & 3 \\
Ragu - Ragu & 2 & 2 \\
Setuju & 3 & 1 \\
\hline
\end{tabular}

Untuk menentukan interval masing-masing kategori dilakukan dengan menggunakan persamaan berikut (Sudjana, 2000):

Panjang Kelas Interval $=\frac{\text { Rentang }}{\text { Banyak kelas interval }}$

Keterangan :

Rentang = Nilai Maksimal - Nilai Minimal

Banyak Kelas Interval = Jumlah Kategori

$$
=\frac{72-24}{3}
$$

Sehingga Panjang Kelas Interval $=16$

Berdasarkan panjang kelas interval yang diperoleh selanjutnya dihitung rentang interval untuk setiap tingkat partisipasi sebagai berikut:

Tabel 4. Rentang interval pada setiap tingkat partisipasi

\begin{tabular}{cll}
\hline No & \multicolumn{1}{c}{ Tingkat Partisipasi } & Interval \\
\hline 1 & Partisipasi Rendah & $24,0=\mathrm{Q} \leq 40,0$ \\
2 & Partisipasi Sedang & $40,0>\mathrm{Q} \leq 56,0$ \\
3 & Partisipasi Tinggi & $56,0>\mathrm{Q} \leq 72,0$ \\
\hline
\end{tabular}

3. Pengaruh variabel bebas terhadap partisipasi anggota kelompok tani di Kampung Sayur Bausasran

Untuk menganalisa pengaruh faktor tingkat pendidikan, mata pencaharian, pengalaman berusahatani sayuran, kinerja Penyuluh dan fasilitasi pemerintah terhadap partisipasi anggota kelompok tani dalam pengelolaan Kampung Sayur Bausasran digunakan analisis kuantitatif dengan menggunakan Analisis Regresi Linier Berganda. Persamaan regresi yang dipergunakan yaitu:

$Y=a+b_{1} D_{1}+b_{2} X_{2}+b_{3} X_{3}+b_{4} X_{4}+b_{5} X_{5}+e$

di mana:

$\mathrm{Y} \quad=$ Tingkat partisipasi (skor)

a $\quad=$ Intersep

bi $\quad=$ Koefisien regresi $\mathrm{Xi}$

$\mathrm{D}_{1} \quad=$ Mata pencaharian utama (dummy variable)

$\mathrm{X}_{2} \quad=$ Pendidikan (tahun)

$\mathrm{X}_{3} \quad=$ Pengalaman berusahatani sayuran (tahun)

$\mathrm{X}_{4} \quad=$ Kinerja Penyuluh (skor)

$\mathrm{X}_{5}=$ Fasilitasi Pemerintah (skor)

$\mathrm{e}=$ Error

Jawaban kuesioner faktor $\mathrm{Y}$ (tingkat partisipasi), $\mathrm{X}_{6}$ (kinerja Penyuluh) dan $\mathrm{X}_{7}$ (fasilitasi pemerintah) merupakan merupakan data ordinal sehingga agar dapat dianalisis secara statistik maka data tersebut harus diubah menjadi data interval menggunakan Methode of Succesive Interval (MSI). MSI adalah suatu metode

Proceedings homepage: $\underline{\text { https://conferenceproceedings.ump.ac.id/index.php/pspfs/issue/view/9 }}$ 
untuk mentransformasikan data dari skala ordinal menjadi data berskala interval. Dalam proses pengolahan data MSI tersebut digunakan bantuan Additional Instrument (Add-Ins) pada Microsoft Excel.

a. Koefisien Determinasi (Adjusted $\mathrm{R}^{2}$ )

Untuk mengetahui ketepatan persamaan regresi yang digunakan maka dihitung koefisien determinasinya (Adjusted $\mathrm{R}^{2}$ ). Nilai Adjusted $\mathrm{R}^{2}$ menunjukkan seberapa besar presentase variasi variabel bebas (independen) pada model regresi linier berganda dalam menjelaskan variasi variabel terikat (dependen).

b. Uji F

Untuk mengetahui ada tidaknya hubungan atau pengaruh nyata semua variabel independen (X) secara bersama-sama terhadap variabel dependen (Y) digunakan Uji F.

Hipotesis yang hendak diuji yaitu :

Ho : $\beta_{1}=\beta_{\mathrm{i}}=0$

Ha : $\beta_{\mathrm{i}} \neq 0$

Kriteria pengujian :

1) Nilai signifikansi $\leq 0,05$ maka Ho ditolak dan Ha diterima, artinya variavel bebas secara bersama - sama berpengaruh signifikan terhadap tingkat partisipasi anggota kelompok tani di Kampung Sayur Bausasran.

2) Nilai signifikansi > 0,05 maka Ho diterima dan Ha ditolak, artinya variabel bebas secara bersama - sama tidak berpengaruh signifikan terhadap tingkat partisipasi anggota kelompok tani di Kampung Sayur Bausasran.

c. Uji T

Untuk mengetahui tingkat pengaruh setiap variabel independen $(\mathrm{X})$ terhadap variabel dependen $(\mathrm{Y})$ secara individual digunakan Uji T. Nilai $t_{\text {hitung }}$ dihitung dengan rumus :

$$
t_{\text {hitung }}=\frac{b i}{S b i}
$$

$$
t_{\text {tabel }}=t(\propto ; n-1)
$$

Keterangan :

$\mathrm{Bi}=$ Koefisien regresi yang diperoleh dari responden

Sbi $=$ Standar error koefisien regresi responden

$\mathrm{N}=$ Jumlah responden

Hipotesis yang hendak diuji yaitu :

Ho : $\beta_{1}=\beta_{\mathrm{i}}=0$

$\mathrm{Ha}: \beta_{\mathrm{i}} \neq 0$

Kriteria pengujian :

1) Nilai signifikansi $\leq 0,05$ maka Ho ditolak dan Ha diterima, artinya variabel bebas secara parsial berpengaruh signifikan terhadap tingkat partisipasi anggota kelompok tani di Kampung Sayur Bausasran.

2) Nilai signifikansi > 0,05 maka Ho diterima dan Ha ditolak, artinya variabel bebas secara parsial tidak berpengaruh signifikan terhadap tingkat partisipasi anggota kelompok tani di Kampung Sayur Bausasran.

\section{HASIL DAN PEMBAHASAN}

Tingkat Partisipasi Anggota Kelompok Tani di Kampung Sayur Bausasran

Tingkat Partisipasi Anggota Kelompok Tani di Kampung Sayur Bausasran dianalisis dengan metode analisis deskriptif untuk mengetahui dan menganalisis data jawaban responden yang diukur menggunakan Skala Likert. Hasil olah data jawaban responden ditampilkan pada tabel 5.

Tabel 5. Kategori Tingkat Partisipasi Anggota Kelompok Tani Pada Setiap Dimensi Dalam Pengelolaan Kampung Sayur Bausasran

\begin{tabular}{clcccc}
\hline No & Dimensi Partisipasi & $\begin{array}{c}\text { Skor } \\
\text { Maksimal }\end{array}$ & Rata-rata Skor & Persentase & Kategori \\
\hline 1 & Pengetahuan & 27 & 23,04 & $85,33 \%$ & Tinggi \\
2 & Kemauan & 21 & 18,81 & $89,57 \%$ & Tinggi \\
3 & Tindakan & 24 & 20,58 & $85,75 \%$ & Tinggi \\
\hline Jumlah & 72 & 62,43 & $86,71 \%$ & Tinggi \\
\hline
\end{tabular}

Sumber : Data diolah.

Hasil analisis menunjukkan skor rata-rata dari ketiga dimensi adalah sebesar 62,43 atau 86,71\% yang berarti tingkat partisipasi anggota Kelompok Tani di Kampung Sayur Bausasran masuk dalam kategori Tinggi. 
Menurut Arnstein (1969) bahwa Partisipasi Tinggi yaitu derajat kekuasaan masyarakat dimana sudah terjadi pembagian hak, tanggung jawab dan wewenang antara masyarakat dan Pemerintah dalam pengambilan keputusan. Masyarakat memiliki pengaruh dalam proses pengambilan keputusan dengan menjalankan kemitraan (partnership) dengan memiliki kemampuan tawar menawar kepada Pemerintah. Pembagian hak, tanggung jawab dan wewenang antara Pemerintah dan masyarakat adalah suatu proses atau tahapan yang diawali dengan adanya komunikasi atau pemberian informasi oleh Pemerintah kepada masyarakat (Dimensi Pengetahuan), yang akan memicu reaksi berupa kemauan (Dimensi Kemauan) dan selanjutnya akan direalisasikan menjadi sebuah tindakan (Dimensi Tindakan).

Skor rata-rata dimensi pengetahuan sebesar 23,04 dapat diartikan bahwa pengetahuan responden mengenai Program Kampung Sayur adalah tinggi. Pengetahuan yang tinggi menunjukkan bahwa terdapat proses komunikasi atau pemberian informasi dari Pemerintah kepada anggota Kelompok Tani mengenai Program Kampung Sayur. Pemberian informasi ini berupa Sosialisasi dan Pelatihan Kampung Sayur yang dilaksanakan oleh Dinas Pertanian dan Pangan Kota Yogyakarta dan Kelurahan Bausasran kepada anggota Kelompok Tani dan masyarakat di wilayah Kampung Bausasran. Pengetahuan yang tinggi diikuti oleh kemauan yang tinggi pula dengan skor rata-rata 18,81 . Skor rata-rata dimensi tindakan sebesar 20,58 atau kategori "Tinggi". Sesuai dengan pernyataan Arnstein (1968) bahwa partisipasi tinggi ditandai dengan adanya pembagian hak, tanggung jawab dan wewenang antara masyarakat dan Pemerintah dalam pengambilan keputusan. Anggota kelompok tani sebagai pengelola Kampung Sayur Bausasran memiliki kewenangan dalam pengelolaan Kampung Sayur Bausasran mulai dari penentuan jenis komoditas yang diusahakan, teknik budidaya yang diterapkan, pemasaran, pembiayaan sampai dengan kemitraan dengan pihak luar, namun tetap dengan pendampingan dari Pemerintah dalam hal ini Dinas Pertanian dan Pangan dan Kelurahan Bausasran.

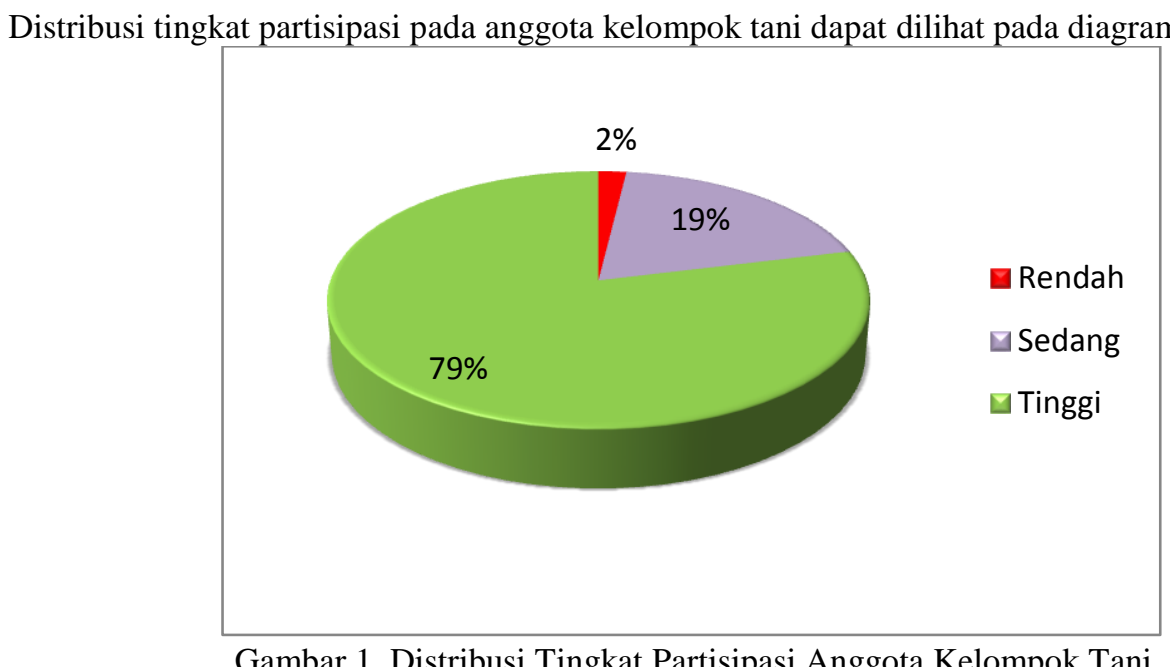

Dari diagram diatas diketahui bahwa dari 52 orang anggota kelompok tani, sebanyak 41 orang atau $79 \%$ berada pada tingkat partisipasi tinggi dengan rincian pengetahuan pada kategori tinggi, kemauan pada kategori tinggi dan tindakan pada kategori tinggi. Sebanyak 10 orang atau 19\% dari anggota kelompok tani berada pada tingkat partisipasi sedang dengan rincian pengetahuan pada kategori sedang, kemauan pada kategori tinggi dan tindakan pada kategori sedang. Sebanyak 1 orang atau $2 \%$ dari anggota kelompok tani berada pada tingkat partisipasi rendah dengan rincian pengetahuan pada kategori rendah, kemauan pada kategori sedang dan tindakan pada kategori rendah.

Skor partisipasi yang telah diperoleh kemudian dikelompokkan pada masing - masing kelompok tani untuk mengetahui tingkat partisipasi masing-masing kelompok tani. Tingkat partisipasi anggota kelompok tani pada setiap kelompok tani di Kampung Sayur Bausasran dapat dilihat pada tabel 6. 
Tabel 6. Tingkat Partisipasi Anggota Kelompok Tani

\begin{tabular}{|c|c|c|c|c|c|c|c|c|}
\hline \multirow{2}{*}{ No } & \multirow{2}{*}{$\begin{array}{l}\text { Kelompok } \\
\text { Tani }\end{array}$} & & \multicolumn{3}{|c|}{ Kategori Partisipasi } & \multirow{2}{*}{ Total } & \multirow{2}{*}{$\begin{array}{c}\text { Skor } \\
\text { Partisipasi }\end{array}$} & \multirow{2}{*}{$\begin{array}{l}\text { Tingkat } \\
\text { Partisipasi }\end{array}$} \\
\hline & & & Rendah & Sedang & Tinggi & & & \\
\hline \multirow[t]{2}{*}{1} & KTD Gemah Ripah & $\sum$ & 0 & 0 & 12 & 12 & 69,75 & Tinggi \\
\hline & & $\%$ & $0.0 \%$ & $0.0 \%$ & $100.0 \%$ & $100.0 \%$ & & \\
\hline \multirow[t]{2}{*}{2} & KWT Amanah & $\sum$ & 0 & 2 & 7 & 9 & 62,77 & Tinggi \\
\hline & & $\%$ & $0.0 \%$ & $22.2 \%$ & $77.8 \%$ & $100.0 \%$ & & \\
\hline \multirow[t]{2}{*}{3} & KTD Sumur Bening & $\sum$ & 0 & 6 & 5 & 11 & 61,00 & Tinggi \\
\hline & & $\%$ & $0.0 \%$ & $54.5 \%$ & $45.5 \%$ & $100.0 \%$ & & \\
\hline \multirow[t]{2}{*}{4} & KTD Bustan Adi & $\sum$ & 0 & 1 & 9 & 10 & 60,70 & Tinggi \\
\hline & & $\%$ & $0.0 \%$ & $10.0 \%$ & $90.0 \%$ & $100.0 \%$ & & \\
\hline \multirow[t]{4}{*}{5} & KTD Bonjowi 4 Dasa & $\sum$ & 1 & 1 & 8 & 10 & 57,95 & Tinggi \\
\hline & & $\%$ & $10.0 \%$ & $10.0 \%$ & $80.0 \%$ & $100.0 \%$ & & \\
\hline & & $\sum$ & 1 & 10 & 41 & 52 & 62,43 & Tinggi \\
\hline & Total & $\%$ & $\%$ & $19.2 \%$ & $78.8 \%$ & $100.0 \%$ & & \\
\hline
\end{tabular}

Sumber : Data diolah

Semua kelompok tani di Kampung Sayur Bausasran memiliki tingkat partisipasi yang tinggi namun dengan skor partisipasi yang berbeda-beda. KTD Gemah Ripah memiliki skor partisipasi tertinggi diantara lima kelompok tani dengan skor 69,75, posisi kedua KWT Amanah dengan skor 61,67, posisi ketiga KTD Sumur Bening dengan skor 61,00, posisi keempat KTD Bustan Adi dengan skor 60,70 dan di posisi kelima KTD Bonjowi 4 Dasa dengan skor 57,97.

Koefisien Determinasi

Hasil uji korelasi determinasi simultan dapat dilihat pada tabel berikut:

Tabel 7. Koefisien Determinasi

\begin{tabular}{|l|r|r|r|r|r|}
\hline \multicolumn{9}{|c|}{ Model Summary } \\
\hline Model & R & R Square & $\begin{array}{c}\text { Adjusted R } \\
\text { Square }\end{array}$ & $\begin{array}{c}\text { Std. Error of the } \\
\text { Estimate }\end{array}$ & Durbin-Watson \\
\hline 1 & $.922^{\mathrm{a}}$ & .850 & .834 & .20885 & 1.973 \\
\hline
\end{tabular}

a. Predictors: (Constant), Pemerintah, Pengalaman, Penyuluh, Mata_Pencaharian, Pendidikan

b. Dependent Variable: Persepsi

Sumber : Hasil analisis

Nilainya sebesar 0,834, artinya pengaruh variabel mata pencaharian utama, pendidikan, pengalaman berusahatani sayuran, kinerja Penyuluh, dan fasilitasi pemerintah secara bersama-sama terhadap tingkat partisipasi (Y) sebesar 83,4\% sedangkan sisanya sebesar 16,6\% dipengaruhi oleh variabel lain diluar penelitian ini.

Uji F

Hasil Uji F dapat dilihat pada tabel berikut :

Tabel 8. Hasil Uji F

\begin{tabular}{|l|l|c|r|r|r|r|}
\hline \multicolumn{7}{|c|}{ ANOVA $^{\text {a }}$} \\
\hline 1 & Rodel & Sum of Squares & Df & Mean Square & F & Sig. \\
\hline & Regression & 11.399 & 5 & 2.280 & 52.263 & $.000^{\mathrm{b}}$ \\
& Total & 2.007 & 46 & .044 & & \\
\hline \multicolumn{2}{l|}{ a. Dependent Variable: Partisipasi } \\
b. Predictors: (Constant), Pemerintah, Pengalaman, Penyuluh, Mata_Pencaharian, Pendidikan \\
\hline
\end{tabular}

Sumber : Hasil analisis Uji F

Berdasarkan tabel 4.20 diperoleh signifikansi 0,00 $<0,05$ maka Ho ditolak berarti secara bersama - sama atau simultan tingkat pendidikan, mata pencaharian utama, pengalaman berusahatani sayuran, kinerja Penyuluh dan fasilitasi pemerintah berpengaruh signifikan terhadap partisipasi anggota kelompok tani di Kampung Sayur Bausasran. 
Uji T

Hasil Uji T dapat dilihat pada tabel berikut :

Tabel 9. Hasil Uji T

\begin{tabular}{|c|c|c|c|c|c|c|}
\hline \multirow{2}{*}{\multicolumn{2}{|c|}{ Model }} & \multicolumn{2}{|c|}{ Unstandardized Coefficients } & $\begin{array}{l}\text { Standardized } \\
\text { Coefficients }\end{array}$ & \multirow[t]{2}{*}{$\mathrm{T}$} & \multirow[t]{2}{*}{ Sig. } \\
\hline & & B & Std. Error & Beta & & \\
\hline \multirow[t]{6}{*}{1} & (Constant) & .075 & .199 & & .374 & .710 \\
\hline & Mata_Pencaharian & .055 & .026 & .127 & 2.084 & .043 \\
\hline & Pendidikan & .208 & .048 & .331 & 4.336 & .000 \\
\hline & Pengalaman & .030 & .009 & .223 & 3.521 & .001 \\
\hline & Penyuluh & .297 & .060 & .375 & 4.979 & .000 \\
\hline & Pemerintah & .307 & .041 & .441 & 7.415 & .000 \\
\hline
\end{tabular}

Sumber : Hasil analisis uji T

Dari hasil perhitungan diperoleh hasil bahwa nilai signifikansi pada semua variabel bebas adalah kurang dari 0,005 sehingga dapat dikatakan bahwa semua variabel bebas secara parsial berpengaruh signifikan terhadap tingkat partisipasi anggota kelompok tani di wilayah Kampung Bausasran.

\section{Analisis Regresi Linear Berganda}

Analisis regresi linear berganda yang dilakukan menghasilkan persamaan regresi:

$\mathrm{Y}=0,075+0,055 . \mathrm{D} 1+0,208 \cdot \mathrm{X} 2+0,030 . \mathrm{X} 3+0,297 . \mathrm{X} 4+0,307 . \mathrm{X} 5$.

a. Mata Pencaharian Utama

Koefisien regresi variabel mata pencaharian utama (D1) adalah sebesar 0,055. Mata pencaharian utama responden didominasi "mengurus rumah tangga" sebanyak 22 orang atau sebesar $42,3 \%$. Hal ini sesuai dengan keadaan kelompok tani di Kampung Bausasran yang anggotanya sebagian besar adalah wanita atau ibu rumah tangga dengan mata pencaharian utamanya "mengurus rumah tangga". Jenis mata pencaharian utama selanjutnya yang mendominasi adalah sebagai "wiraswasta" sebanyak 17 orang sebesar 32,7\%. Responden dengan kedua jenis pekerjaan atau mata pencaharian utama ini memiliki waktu yang lebih fleksibel untuk berpartisipasi dalam pengelolaan Kampung Sayur Bausasran. Anggota kelompok tani yang memiliki pekerjaan utama pada sektor formal seperi PNS/TNI/Polri/Karyawan Swasta hanya dapat berpartisipasi pada kegiatan Kampung Sayur pada hari libur, akhir pekan atau saat mereka memiliki waktu luang. Budiharjo dan Sutarjo (2009) mengungkapkan bahwa waktu luang seseorang terlibat dalam organisasi atau kegiatan di masyarakat juga dipengaruhi oleh jenis pekerjaannya, banyak warga yang telah disibukkan oleh pekerjaan utama atau kegiatannya sehari-hari kurang tertarik untuk mengikuti pertemuan, diskusi atau seminar.

\section{b. Tingkat Pendidikan}

Koefisien regresi variabel tingkat pendidikan adalah sebesar 0,208 berarti faktor pendidikan berpengaruh positif terhadap tingkat partisipasi anggota kelompok tani di wilayah Kampung Bausasran. Semakin tinggi pendidikan anggota kelompok tani maka partisipasinya dalam pengelolaan Kampung Sayur Bausasran juga akan semakin tinggi. Pendidikan responden didominasi oleh SMA/SLTA/sederajat atau telah menempuh pendidikan selama 12 tahun sebanyak 29 orang atau sebesar 55,8\%. Dari data tersebut dapat dikatakan bahwa sebagian besar responden telah memiliki pendidikan yang cukup tinggi. Kegiatan pertanian di Kota Yogyakarta dikembangkan dengan menerapkan teknologi yang memungkinkan penanaman tanaman pada lahan sempit dan menghemat media tanam serta menghemat air seperti pertanian dengan sistem vertikultur, hidroponik, aquaponik dan penggunaan sistem irigasi otomatis yang saat ini banyak dikembangkan di Kota Yogyakarta termasuk di Kampung Sayur Bausasran. Anggota kelompok tani dengan tingkat pendidikan yang tinggi akan lebih mudah dalam menerima dan mengadopsi teknologi.

\section{c. Pengalaman Berusahatani Sayuran}

Koefisien regresi variabel pengalaman berusahatani sayuran sebesar 0,030 berarti pengalaman usahatani sayuran berpengaruh positif terhadap tingkat partisipasi anggota kelompok tani di Kampung Sayur Bausasran. Semakin lama pengalaman berusahatani sayuran maka partisipasi anggota kelompok tani dalam pengelolaan Kampung Sayur Bausasran akan semakin tinggi. Semakin lama pengalaman berusahatani menyebabkan anggota kelompok tani telah memiliki banyak pengalaman dalam mengatasi berbagai kendala dalam usahatani sehingga lebih percaya diri untuk berpartisipasi dalam kegiatan Kampung Sayur. Salah satunya dalam hal pengendalian hama tanaman sayuran, anggota kelompok tani telah memiliki pengalaman menggunakan jenis pestisida nabati yang berbeda untuk jenis hama yang berbeda. Hal ini dikarenakan mereka telah memiliki pengalaman dalam hal uji coba berbagai jenis pestisida nabati dan pengaruhnya terhadap jenis hama tertentu. 


\section{d. Kineja Penyuluh}

Koefisien regresi variabel kinerja Penyuluh sebesar 0,297 berarti bahwa variabel kinerja Penyuluh berpengaruh positif terhadap partisipasi anggota kelompok tani di Kampung Sayur Bausasran. Semakin baik kinerja Penyuluh menurut anggota kelompok tani maka partisipasinya juga akan semakin tinggi. Tanggapan responden terhadap kinerja Penyuluh adalah sebesar 77,69\%. Kinerja Penyuluh dalam kategori Tinggi terutama terlihat pada pernyataan "Penyuluh selalu datang bila diminta oleh petani maupun kelompok tani". Kehadiran Penyuluh di kelompok tani sangat penting dalam memberikan motivasi dan mendorong partisipasi anggota kelompok tani dalam pengelolaan Kampung Sayur. Penyuluh Pertanian memiliki peran penting untuk meningkatkan Pengetahuan, Sikap dan Ketrampilan (PKS) anggota kelompok tani agar mereka mau dan mempu mengelola usahataninya dengan baik dan mencapai produksi dan produktivitas yang optimal.

\section{e. Fasilitasi Pemerintah}

Koefisien regresi variabel fasilitasi pemerintah sebesar 0,307 berarti variabel fasilitasi pemerintah berpengaruh positif terhadap partisipasi anggota kelompok tani di Kampung Sayur Bausasran. Semakin baik tanggapan anggota kelompok tani terhadap fasilitasi pemerintah maka partisipasinya juga akan semakin tinggi. Hasil penelitian ini menunjukkan tanggapan responden terhadap fasilitasi Pemerintah sebesar 63,72\% atau kategori Sedang. Jenis fasilitasi yang diberikan oleh Pemerintah dianggap sudah cukup, namun jumlahnya masih dianggap kurang. Hal tersebut mempengaruhi tingkat partisipasi anggota kelompok tani dalam pengelolaan Kampung Sayur Bausasran. Menurut Watson dalam Soetomo (2006) bahwa terdapat beberapa faktor yang menghambat partisipasi masyarakat antara lain kendala yang berasal dari kepribadian individu salah satunya adalah ketergantungan. Ketergantungan masyarakat terhadap pemerintah dalam pelaksanaan kegiatan pembangunan merupakan hambatan dalam mewujudkan partisipasi atau keterlibatan masyarakat secara aktif, karena rasa ketergantungan ini masyarakat tidak memiliki inisiatif untuk melaksanakan pembangunan atau prakarsa mereka sendiri.

\section{KESIMPULAN}

Kesimpulan dari penelitian ini adalah sebagai berikut:

1. Tingkat partisipasi anggota kelompok tani di Kampung Sayur Bausasran termasuk dalam kategori Tinggi.

2. Tingkat pendidikan, mata pencaharian utama, pengalaman berusahatani sayuran, kinerja Penyuluh dan fasilitasi pemerintah berpengaruh secara signifikan terhadap partisipasi anggota kelompok tani di Kampung Sayur Bausasran.

\section{UCAPAN TERIMA KASIH}

Pelaksanaan penelitian “Tingkat Partisipasi Anggota Kelompok Tani Di Kampung Sayur Bausasran” ini tidak akan dapat terselesaikan dengan baik tanpa bantuan dari banyak pihak. Peneliti mengucapkan terimakasih kepada :

1. Bapak dan Ibu Dosen dan Staf Program Studi Magister Agribisnis Fakultas Pertanian UPN "Veteran" Yogyakarta atas ilmu dan bimbingan yang diberikan kepada peneliti.

2. Ketua Gapoktan Bausasran, Ketua dan pengurus Kampung Sayur Bausasran, Ketua, pengurus dan anggota kelompok tani se Kampung Bausasran, Kecamatan Danurejan yang telah bersedia memberikan data-data yang dibutuhkan untuk penelitian ini.

3. Kepala Dinas Pertanian dan Pangan Kota Yogyakarta, Kepala Bidang Pangan dan Kepala Seksi Ketahanan Pangan yang telah membantu dalam penyediaan data sekunder untuk penelitian ini.

4. Bapak, Ibu, Saudara dan segenap keluarga yang selalu memberikan dukungan dan semangat bagi peneliti.

5. Semua pihak yang tidak dapat penulis sebutkan satu per satu, terimakasih atas bantuan, dukungan dan doa untuk peneliti sehingga tesis ini dapat diselesaikan dengan baik.

\section{DAFTAR PUSTAKA}

Andry., Utama, S.P, Widiono. 2020. Tingkat Partisipasi Petani Pada Program Penguatan Kelembagaan Masyarakat Tani Berbasis Karet Di Kabupaten Musi Rawas. Jurnal Ekonomi Pertanian dan Agribisnis (JEPA). Vol 4 (3). 493.506. https://jepa.ub.ac.id/index.php/jepa/article/view/431 (diunduh 5 Juli 2021).

Arnstein, S. 1969. Planning in the Face of Power. Journal of the American Institute of Planners. Vol. 35 (4). http://repository.upi.edu/35264/9/ STE_1203531_Bibliography.pdf (diunduh 5 Juni 2020).

Badan Ketahanan Pangan dan Penyuluhan DIY. 2018. Peta Food Security And Vulnerability Atlas (FSVA) Tingkat Kecamatan Daerah Istimewa Yogyakarta Tahun 2018. Yogyakarta : BKPP DIY.

Riduwan. 2013. Metode dan Teknik Menyusun Proposal Penelitian (Untuk Mahasiswa S1, S-2, dan S-3). Bandung: Alfabeta.

Soetomo. 2006. Strategi-Strategi Pembangunan Masyarakat. Yogyakarta : Pustaka Belajar.

Proceedings homepage: https://conferenceproceedings.ump.ac.id/index.php/pspfs/issue/view/9 
Sudjana. 2000. Statistika Untuk Ekonomi dan Niaga. Bandung : Tarsito.

Wahyuni, R.P., Sudibyo, R.P, Amir, N.O. 2021. Faktor-Faktor Yang Berperan Terhadap Tingkat Partisipasi Petani Dalam Budidaya Tanaman Organik Di Kecamatan Junrejo Kota Batu. Jurnal Ekonomi Pertanian dan Agribisnis (JEPA). Vol 5 (2), 544-560. https://jepa.ub.ac.id/index.php/ jepa/article/view/815 (diunduh 5 Juli 2021). 